\title{
A new genus and two new species of Anteroporidae (Cestoda: Lecanicephalidea) from the darkspotted numbfish, Narcine maculata (Torpediniformes: Narcinidae), off Malaysian Borneo
}

\author{
Kirsten Jensen ${ }^{1}$, Pavel Nikolov ${ }^{2}$ and Janine N. Caira ${ }^{3}$ \\ ${ }^{1}$ Department of Ecology and Evolutionary Biology and the Biodiversity Institute, University of Kansas, 1200 Sunnyside Ave., \\ Lawrence, Kansas 66045, USA; \\ ${ }^{2}$ Bulgarian Academy of Sciences, Institute of Biodiversity and Ecosystem Research, 2 Gagarin St., 1113 Sofia, Bulgaria; \\ ${ }^{3}$ Department of Ecology and Evolutionary Biology, University of Connecticut, Unit 3043, 75 N. Eagleville Rd., Storrs, \\ Connecticut 06269-3043, USA
}

\begin{abstract}
The cestode fauna of the darkspotted numbfish, Narcine maculata (Shaw) (Torpediniformes: Narcinidae), from Malaysian Borneo was examined for the first time. This work resulted in the discovery of a new genus and two new species of Anteroporidae (Lecanicephalidea). Sesquipedalapex comicus gen. n., sp. n. was erected on the basis of the peculiarities of its scolex, in particular its possession of an extremely long apical modification of the scolex proper, which readily distinguishes it from the other genus in the family. The genus is also distinct in its possession of acetabula that are in the form of suckers, rather than bothridiate in form. This species was found to deeply embed its elongate apical structure for much of its length within the intestinal mucosa, provoking a papilliform expansion of the outer wall of the spiral intestine at the site of attachment. The second new species, Anteropora klosmamorphis sp. $\mathrm{n}$., is readily distinguished from its congeners on the basis of testis number and bothridial shape. Both new species are hyperapolytic. The diagnosis of Anteroporidae is amended to accommodate both new taxa. This increases the total number of genera in the family to two, and the total number of species to five.
\end{abstract}

Keywords: Cestoda, Lecanicephalidea, Narcine, new genus, Malaysian Borneo

The darkspotted numbfish, Narcine maculata (Shaw), was examined for cestodes for the first time. A remarkably large number of detached proglottids was observed upon examination of the contents of the spiral intestine. Closer investigation revealed that these detached proglottids represented two different hyperapolytic species, both belonging to the lecanicephalidean family Anteroporidae Euzet, 1994. The scolices and strobilae of one of these species were subsequently found deeply embedded in the mucosa of the spiral intestine. The latter species was determined to represent a new genus; the other a new species of Anteropora Subhapradha, 1955. These new taxa are described herein and the familial diagnosis is emended to include this, the second genus of Anteroporidae.

\section{MATERIALS AND METHODS}

A female specimen of Narcine maculata measuring $35.5 \mathrm{~cm}$ in total length, was collected using a bottom trawl by the Kuching Fisheries vessel K. K. Manchong, off the coast of southern Sarawak in Malaysian Borneo $\left(02^{\circ} 49^{\prime} 01.2^{\prime \prime} \mathrm{N}, 110^{\circ} 52^{\prime} 47.16^{\prime \prime} \mathrm{E}\right)$, in the South China Sea in April, 2004. The spiral intestine was removed, opened with a longitudinal incision, fixed in $10 \%$ buffered formalin in the field, and subsequently transferred to $70 \%$ ethanol for storage. Images of the host (No. BO-408) can be viewed in the elasmobranch host component (http://tapewormdb.uconn.edu/hosts.php) of the Global Cestode Database (http:// tapeworms.uconn.edu). Tapeworms were removed from the spiral intestine in the laboratory. Entire worms, scolices, strobilar fragments, and detached proglottids were prepared as whole mounts for light microscopy as follows. Specimens were stained with Delafield's haematoxylin, dehydrated in a graded ethanol series, cleared in methyl salicylate, and mounted on glass slides in Canada balsam. Specimens for serial sectioning were dehydrated in a graded ethanol series, stained with fast green, cleared in xylene, and embedded in paraffin. Serial sections were cut at $6 \mu \mathrm{m}$ intervals with an Olympus CUT4060 retracting rotary microtome, and were subsequently attached to glass slides with $10 \%$ sodium silicate, stained in Delafield's haematoxylin, counterstained in eosin, cleared in xylene, and mounted in Canada balsam. Semi-permanent egg mounts were prepared as follows: gravid proglottids were placed in lactophenol for $1 \mathrm{~h}$, transferred to glass slides, broken open with insect pins, and mounted in lactophenol under a coverslip ringed with clear nail polish. Specimens for scanning electron microscopy (SEM) were transferred 
to distilled water, post-fixed in $1 \%$ osmium tetroxide overnight, dehydrated in a graded ethanol series, transferred to hexamethyldisilazane (Ted Pella, Inc., Redding, California) and, after removal of the latter, allowed to air dry. Specimens were subsequently mounted on aluminium stubs on double-sided carbon tape, and sputter coated with $35 \mathrm{~nm}$ of gold/palladium and examined with a LEO/Zeiss 1550 field emission scanning electron microscope.

All aspects of light microscopy were conducted using a Zeiss Axioskop 2 compound microscope. Illustrations were prepared with the aid of a drawing tube. Photographs were taken using a Leica DFC 480 digital camera. Measurements were made using an ocular micrometer or the image analysis software OpenLab Demo 4.0.4 and are given in micrometres unless otherwise stated. For each measurement, the range is followed in parentheses by the mean, standard deviation, number of worms measured, and number of measurements taken if more than one measurement was taken per worm.

Museum abbreviations used are as follows: IPCAS, Institute of Parasitology, Academy of Sciences of the Czech Republic, České Budějovice, Czech Republic; LRP, Lawrence R. Penner Parasitology Collection, University of Connecticut, Storrs, Connecticut, USA; MZUM(P), Muzium Zoologi, Universiti Malaya, Kuala Lumpur, Malaysia; SBC, Sarawak Biodiversity Center, Kuching, Sarawak, Malaysia; USNPC, United States National Parasite Collection, Beltsville, Maryland, USA. Microthrix terminology follows Chervy (2009). Scolex terminology follows Caira et al. (1999).

\section{RESULTS}

\section{Sesquipedalapex gen. n.}

Diagnosis: Worms hyperapolytic. Scolex with 4 acetabula and apical modification of scolex proper housing apical organ; acetabula simple, sessile, sucker-like, facially unmodified; apical modification of scolex proper highly elongated, with apical aperture, expanded at apex to house apical organ; apical organ muscular and glandular, non-eversible; posterior portion of scolex posterior to acetabula elongate, containing glandular tissue. Proglottids craspedote; detached proglottids with conspicuous anterior, vacuous spherical region, anterior fifth of surface covered with gladiate spinitriches. Testes 6 , in single column anterior to ovary. Vas deferens extending from near oötype to cirrus-sac. External and internal seminal vesicles absent. Cirrus-sac elliptical; cirrus armed. Ovary irregularly lobed in frontal view, irregular in cross-section; each lobe consisting of $\sim 3$ sublobes. Vagina extending from oötype along poral side of proglottid to enter genital atrium posterior to or at same level as cirrus-sac. Genital pores marginal to submarginal, irregularly alternating. Uterus saccate, extending along median line of proglottid to anterior margin of field of testes. Vitellarium follicular; follicles in 2 lateral fields; each field consisting of 1 to 2 irregular columns of follicles, extending from near posterior margin proglottid to level of genital pore. Excretory ducts 4, arranged in 1 dorsal and 1 ventral pair, branched, opening to outside at multiple points along length of scolex and in velum at posterior of proglottids. Eggs single, spherical, with numerous small regularly spaced surface protuberances, without filaments. Parasites of numbfishes (Narcinidae) in the South China Sea. Anteroporidae, Lecanicephalidea. Type and only known species: Sesquipedalapex comicus sp. $\mathrm{n}$.

E t y molog y: From sesquipedalis (adj., L., one and one-half feet in length) and apex (noun, masc., L., apex or tip), referring to the excessively long apical modification of the scolex proper.

Remarks. The fact that Sesquipedalapex is hyperapolytic and bears proglottids with few testes (4 or 6 ) arranged in a single column, places the genus in the Anteroporidae. It differs conspicuously from Anteropora, the only other genus in the family, in its possession of an extremely long apical modification of the scolex proper, rather than one that is small and cone-like. In addition, its acetabula are entirely sessile (rather than free posteriorly) and it exhibits a concentration of glandular tissue in the scolex proper posterior to the acetabula that is not seen in Anteropora. Furthermore, Anteropora does not appear to exhibit excretory ducts that open to the outside throughout the length of the scolex, as is seen in Sesquipedalapex. However, while these criteria serve to distinguish Sesquipedalapex from Anteropora japonica (Yamaguti, 1934) Euzet, 1994 and Anteropora leelongi Jensen, 2005, the fact that Anteropora indica Subhapradha, 1955 is known only from detached proglottids, limits the application of these criteria with respect to this species at this time.

\section{Sesquipedalapex comicus sp. n.}

Figs. 1-3

Description (Based on 1 complete strobila with scolex without apical organ, 6 incomplete worms with scolices, 3 incomplete worms with scolices without apical organ, 3 apical organs, 10 strobilar fragments, 10 detached mature and 10 detached gravid proglottids; cross-section series of 2 detached mature and 1 detached gravid proglottid; 4 scolices, 1 strobila, 2 detached proglottids, and 1 gravid proglottid disrupted to reveal eggs examined with SEM; 4 lactophenol preparations of eggs).

Worms up to at least $47.4 \mathrm{~mm}$ long; maximum width at terminal proglottid; proglottids up to 372 in number, hyperapolytic. Scolex with 4 acetabula, highly elongated apical modification of scolex proper and apical organ, $727-4,668(3,091 \pm 1,411 ; 7)$ long by $143-221(187 \pm 25$; $10)$ wide at level of acetabula; scolex proper posterior to acetabula extensive, $220-862(455 \pm 202 ; 10)$ long by 69-221 (173 $\pm 49 ; 10)$ wide, containing intensely-staining glandular tissue. Acetabula in form of suckers, round to oval, $68-117(93 \pm 13 ; 10 ; 25)$ long by $62-96(74 \pm 10$; $10 ; 23)$ wide. Apical modification of scolex proper elongate, $420-4,317(3,051 \pm 1,486 ; 6)$ long by $94-308$ $(143 \pm 60 ; 11)$ wide, muscular, with aperture at apex, housing apical organ. Apical organ variable in shape, $102-209$ (143 $\pm 34 ; 9)$ long by $140-230(183 \pm 29 ; 9)$ 


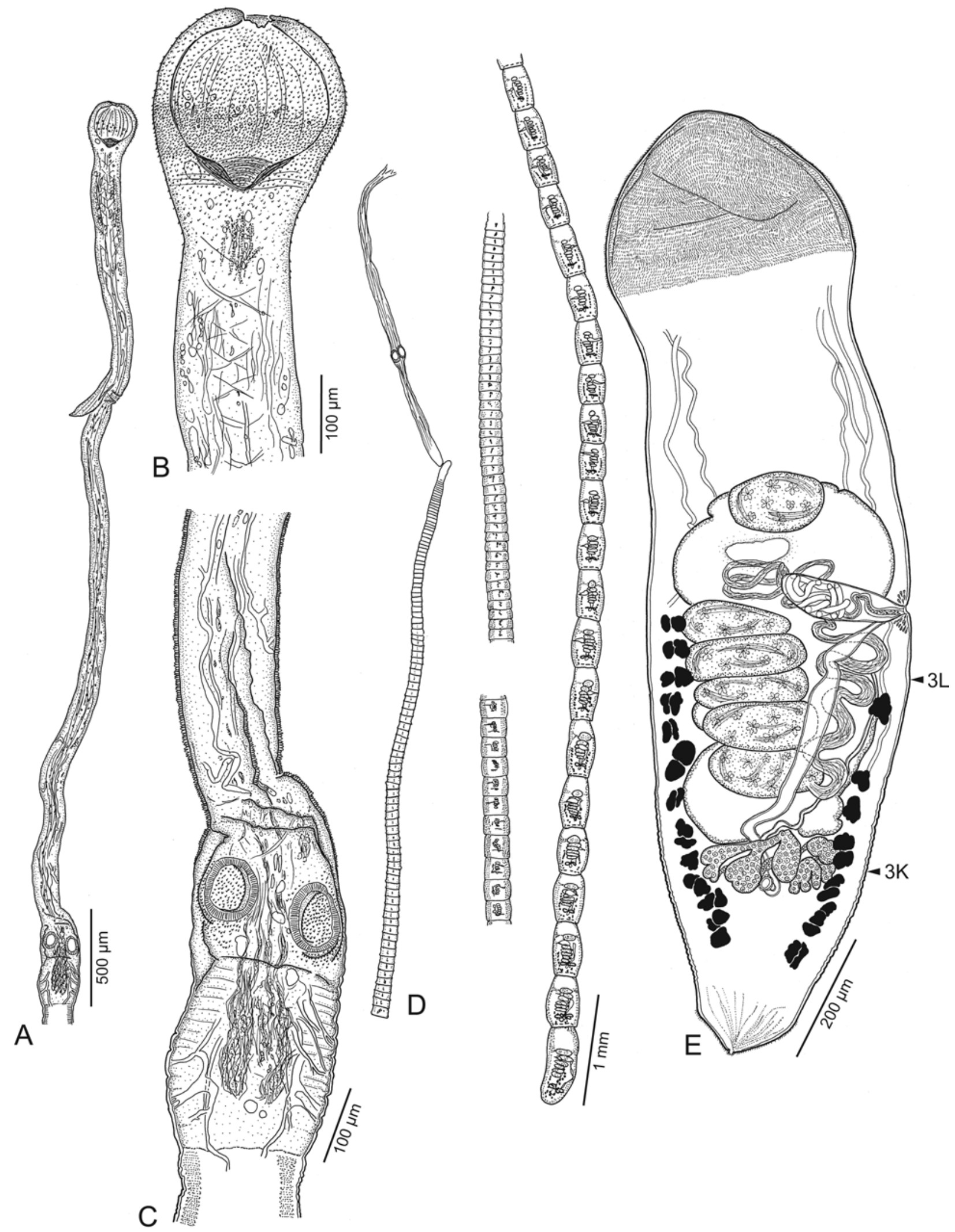

Fig. 1. Line drawings of Sesquipedalapex comicus sp. n. A - scolex; B - apical modification of scolex proper and apical organ; $\mathbf{C}$ - posterior region of scolex proper; D - whole worm; $\mathbf{E}$ - detached proglottid (arrowheads indicate location of sections in Fig. 3K and L). 
wide, non-eversible, muscular, with dispersed glandular tissue. Cephalic peduncle absent.

Scolex proper (Fig. 2D, E, K), suckers (Fig. 2G, H), and apical modification of scolex proper (Fig. 2C) with acicular to capilliform filitriches; sucker rims also with rostrate spinitriches with irregular, broad bases (Fig. $2 \mathrm{G}$, $\mathrm{H}$ ); anterior-most region of apical modification of scolex proper also with narrow rostrate spinitriches with inconspicuous bases (Fig. 2C). Proglottids with capilliform filitriches (Fig. 2L-N), and gladiate spinitriches restricted to anterior spherical region (Fig. 2L) and scolopate spinitriches restricted to posterior margins (Fig. 2M, N).

Proglottids craspedote, non-laciniate; immature proglottids initially wider than long, becoming longer than wide, maximum width $200-350(289 \pm 45 ; 10)$. Terminal immature proglottids $331-787(594 \pm 130 ; 10)$ long by 173-305 (260 $\pm 48 ; 10)$ wide. Detached mature and gravid proglottids conical or teardrop-shaped, with conspicuous anterior vacuous spherical region; detached mature proglottids $891-1,362(1,133 \pm 179 ; 10)$ long by $357-427$ $(387 \pm 26 ; 10)$ wide; detached gravid proglottids 1,147 $1,622(1,399 \pm 171 ; 10)$ long by $408-574(466 \pm 47 ; 10)$ wide; anterior spherical region 304-545 (429 $\pm 86 ; 10)$ long by $341-427(380 \pm 27 ; 10)$ wide in detached mature proglottids, $317-611(477 \pm 104 ; 10)$ long by $384-515$ $(453 \pm 39 ; 10)$ wide in detached gravid proglottids. Testes $6(6 \pm 0 ; 31)$ in number, arranged in single column anterior to ovary, $56-169(94 \pm 23 ; 20 ; 79)$ long by $84-223$ $(161 \pm 32 ; 20 ; 79)$ wide in detached mature and gravid proglottids; anterior-most testis often largest, conspicuously separated from remaining testes. Vas deferens sinuous, extending along poral side of proglottid from oötype to enter cirrus-sac at anterior margin. External and internal seminal vesicles absent. Cirrus-sac elliptical, anterior to or overlapping with second anterior-most testis, oriented perpendicular to proglottid or angled slightly anteriorly, $105-185(140 \pm 29 ; 10)$ long by $30-59(47 \pm 9 ; 10)$ wide in detached mature proglottids, 140-200 (172 \pm 24 ; 10) long by $55-75(63 \pm 7 ; 10)$ wide in detached gravid proglottids. Cirrus coiled, armed with spinitriches. Genital pores marginal to submarginal, irregularly alternating, $45-54 \%(50 \% \pm 3 ; 10)$ from posterior end of proglottid in detached mature proglottids, $45-55 \%(52 \% \pm 3 ; 10)$ from posterior end in detached gravid proglottids; genital atrium at level of second anterior-most testis. Ovary irregularly lobed in shape in frontal view, irregular in cross-section, $59-122(90 \pm 20 ; 10)$ long by $92-228(148 \pm 45 ; 10)$ wide in detached mature proglottids, $57-147(103 \pm 27 ; 10)$ long by $178-323(257 \pm 48 ; 10)$ wide in detached gravid proglottids; each lobe consisting of $\sim 3$ lobules. Vagina weakly sinuous, initially thick-walled with layer of large, intensely staining cells, extending from oötype along poral side of proglottid to enter genital atrium posterior to, or at same level as, cirrus-sac; seminal receptacle not observed; vaginal sphincter absent. Uterus thick-walled, extending from level of ovarian bridge along median line of proglottid to anterior extent of field of testes; uterine duct entering uterus at approximately midlevel; uterine pore absent. Vitellarium follicular; vitelline follicles in 2 lateral fields, $13-57(32 \pm 10 ; 20 ; 60)$ long by $10-34(21 \pm 7$; $20 ; 60)$ wide in detached mature and gravid proglottids; each field consisting of 1 to 2 irregular columns of follicles, extending from near posterior margin of proglottid to genital pore in anti-poral field and stopping well short of genital pore in poral field. Excretory ducts 4, lateral, in 1 dorsal and 1 ventral pair, with lateral branches, opening to outside at multiple points throughout length of scolex (Fig. 3I, J) and at proglottid velum. Eggs single, spherical, $14-16(15 \pm 0.6 ; 15)$ in diameter (Fig. 3F, G), with numerous small, regularly spaced surface protuberances, without polar filaments, released by eversion of uterus through dehiscence at mid-level of proglottid.

Type and only known host: Narcine maculata (Shaw), the darkspotted numbfish (Torpediniformes: Narcinidae) (Host No. BO-408).

Type and only known locality: South China Sea off southern Sarawak $\left(02^{\circ} 49^{\prime} 01.2^{\prime \prime} \mathrm{N}, 110^{\circ} 52^{\prime} 47.16^{\prime \prime} \mathrm{E}\right)$, Malaysia.

Site of infection: Spiral intestine.

Type material: Holotype (complete strobila with scolex without apical organ) (MZUM[P] 2010.34[H]), 6 paratypes (1 incomplete worm with scolex, 1 incomplete worm with scolex without apical organ, 1 strobilar fragment, 1 detached mature and 1 detached gravid proglottid; 1 lactophenol preparation of eggs) (MZUM[P] 2010.35[P]-40[P]); 5 paratypes ( 1 incomplete worm with scolex, 1 strobilar fragment, 1 detached mature and 1 detached gravid proglottid; 1 lactophenol preparation of eggs) (SBC P-00036-00040); 4 paratypes (1 incomplete worm with scolex, 1 strobilar fragment, 1 detached mature and 1 detached gravid proglottid) (IPCAS C-595); 20 paratypes (2 incomplete worms with scolices, 1 incomplete worm with scolex without apical organ, 2 apical organs, 4 strobilar fragments, 4 detached mature and 4 detached gravid proglottids; cross-section series of 1 detached mature and 1 detached gravid proglottid; 1 lactophenol preparation of eggs) (USNPC 104126); and 14 paratypes (1 incomplete worm with scolex, 1 incomplete worm with scolex without apical organ, 1 apical organ, 3 strobilar fragments, 3 detached mature and 3 detached gravid proglottids; crosssection series of 1 detached mature proglottid; 1 lactophenol preparation of eggs) (LRP 7508-7523); 8 paratypes prepared for SEM retained in senior author's personal collection.

Etymology: This species is named for its comically elongated scolex (i.e., comicus, L., comical).

Remarks. Given that Anteropora indica is known only from free proglottids, and most of the characters given above to distinguish Sesquipedalapex from Anteropora rely on scolex morphology, some treatment of the differences between Sesquipedalapex comicus and A. indica is in order. The new species differs conspicuously from A. indica, as illustrated by Subhapradha (1955; fig. 1), in its possession of 6 , rather than 4 testes per proglottid. However, it is important to note that Subhapradha also 


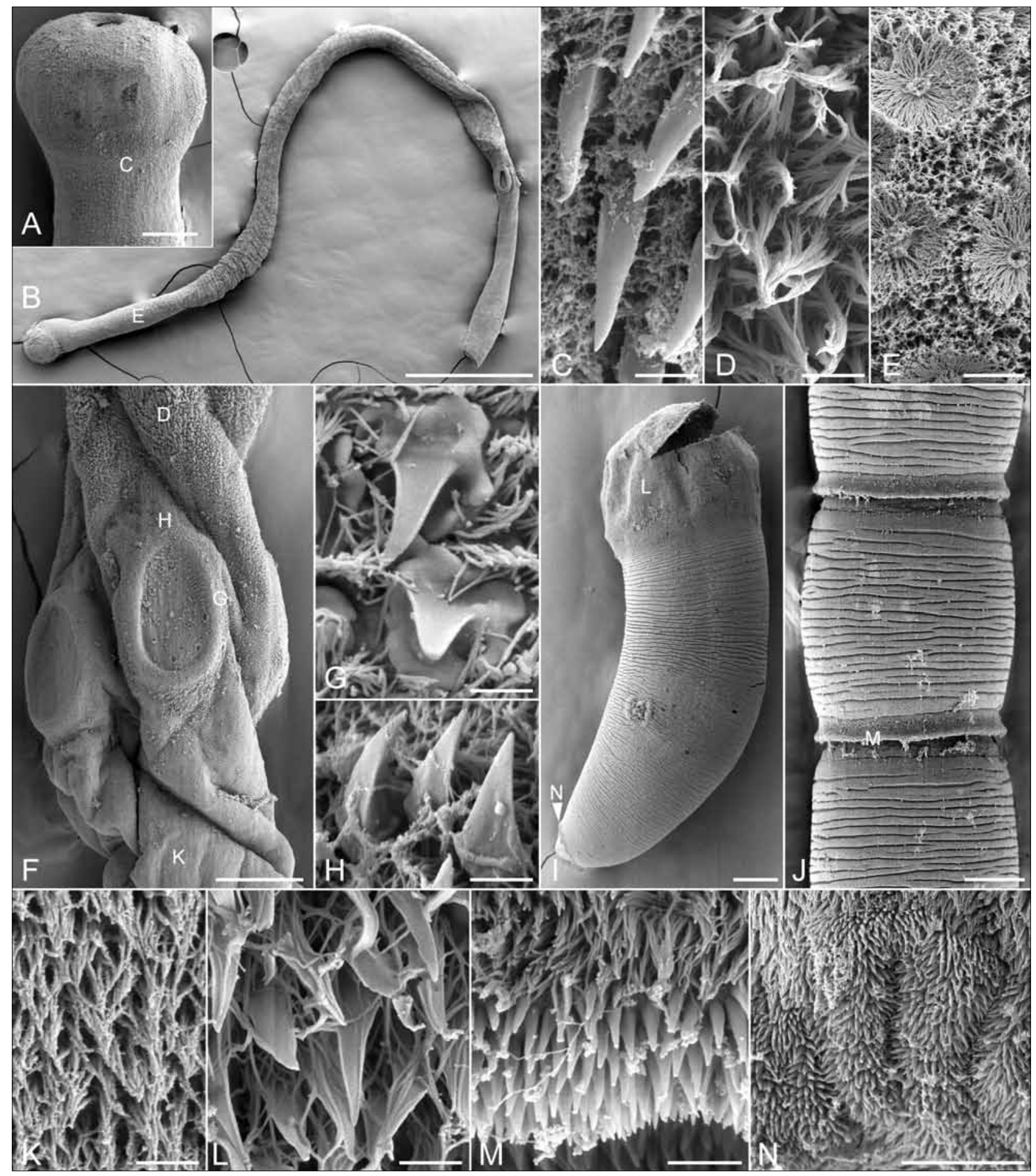

Fig. 2. Scanning electron micrographs of Sesquipedalapex comicus sp. n. A-apical organ; $\mathbf{B}$ - scolex; $\mathbf{C}$ - surface of apical modification of scolex proper with narrow rostrate spinitriches without broad bases and acicular filitriches; $\mathbf{D}$ - surface of scolex proper immediately anterior to acetabula with acicular to capilliform filitriches; $\mathbf{E}$ - surface of scolex proper slightly posterior to apical organ with acicular filitriches; $\mathbf{F}$ - scolex at level of acetabula; $\mathbf{G}$ - surface of sucker rims with rostrate spinitriches with broad bases and acicular filitriches; $\mathbf{H}$ - anterior surface of sucker rims with rostrate spinitriches with broad bases and acicular filitriches; $\mathbf{I}-$ detached proglottid; $\mathbf{J}$ - strobila of immature proglottids; $\mathbf{K}$ - surface of scolex proper posterior to acetabula with acicular filitriches; $\mathbf{L}-$ surface of anterior spherical region of detached proglottid with gladiate spinitriches and capilliform filitriches; $\mathbf{M}$ - surface of posterior margin of immature proglottid (velum) with scolopate spinitriches and capilliform filitriches; $\mathbf{N}$ - surface of posterior margin of detached proglottid (velum) with scolopate spinitriches and capilliform filitriches. Small letters indicate location of details shown in the referenced figure. Scale bars: A, E, F, J = $50 \mu \mathrm{m} ; \mathrm{B}=500 \mu \mathrm{m} ; \mathrm{C}, \mathrm{G}, \mathrm{H}, \mathrm{K}, \mathrm{L}=1 \mu \mathrm{m} ; \mathrm{D}, \mathrm{M}=2 \mu \mathrm{m} ; \mathrm{I}=100 \mu \mathrm{m} ; \mathrm{N}=10 \mu \mathrm{m}$. 


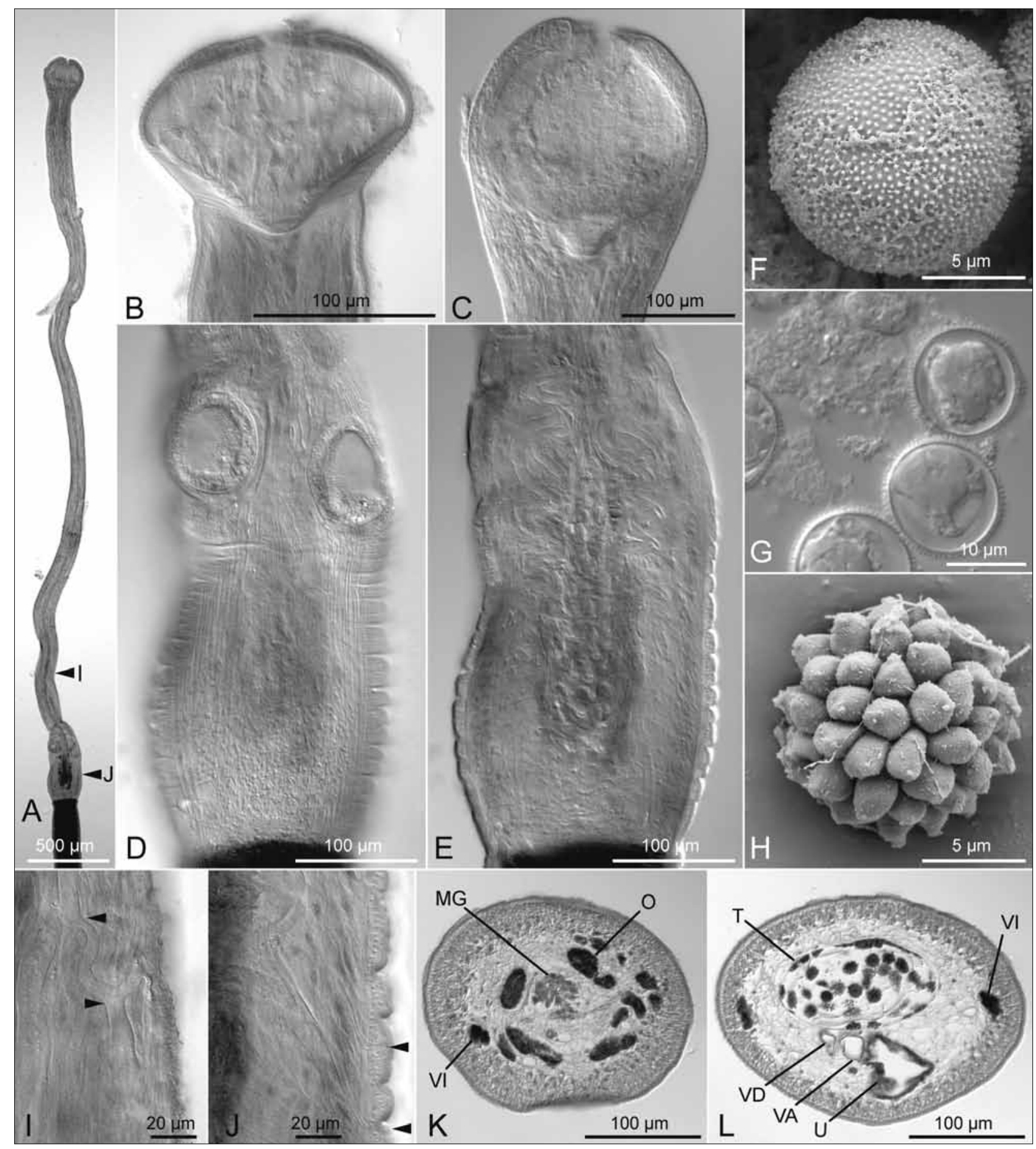

Fig. 3. Light (A-E, G, I-L) and scanning electron (F, H) micrographs of Sesquipedalapex comicus sp. $\mathrm{n}$. A - scolex (arrowheads indicate location of light micrographs in Fig. 3I and J); B, C - variation in form of apical organ; D - scolex at level of acetabula; $\mathbf{E}$ - scolex at level of acetabula, showing intensely staining glandular tissue and excretory vessels; $\mathbf{F}$ - egg, showing regularly spaced surface protuberances; $\mathbf{G}$ - eggs; $\mathbf{H}$ - spermatocytes with developing spermatids; I - excretory vessels in scolex proper anterior to acetabula (arrowheads indicate branching); $\mathbf{J}$ - excretory vessels in scolex proper posterior to acetabula (arrowheads indicate opening to the outside); $\mathbf{K}$ - cross-section of detached mature proglottid at level of ovary; $\mathbf{L}$ - cross-section of detached mature proglottid between ovary and cirrus-sac. Abbreviations: MG - Mehlis' gland; O - ovary; T - testis; U - uterus; VA - vagina; VD - vas deferens; VI - vitelline follicles. 
reported that 6 of the 60 proglottids she examined had 3 , 5 , or 6 testes. The proglottid of $S$. comicus bears a poral field of vitelline follicles that is shorter than the anti-poral field, whereas the poral and anti-poral fields of vitelline follicles are symmetrical in $A$. indica. Finally, the uterine duct also joins the uterus much more posteriorly in $A$. indica than it does in S. comicus.

The remarkably elongate scolex of $S$. comicus appears to function particularly effectively in attachment to the surface of the mucosa of the spiral intestine of its host. Specimens of this cestode were extremely difficult to remove intact from host tissue as they were found to embed their entire scolex deeply within the mucosa. While insufficient material was found to allow for the histological work required for description of the pathology associated with this species in detail, on a gross morphological level, attached worms were found to provoke conspicuous papilliform expansions of the outer wall of the spiral intestine at the site of attachment (Fig. 4). Given that one scolex with a short $(400 \mu \mathrm{m})$ apical modification of the scolex proper was found and that the scolices excised from the host spiral intestine exhibited extensively long apical modifications of the scolex proper $(2.6-4.3 \mathrm{~mm})$, it appears that the apical modification of the scolex proper grows into the intestinal mucosa as the worm matures. The scolices of worms that had been detached from the surface of the mucosa were completely encased in a relatively inflexible fibrous sheath, presumably of host origin.

\section{Anteropora klosmamorphis sp. n.}

Figs. 5-7

Description (Based on 16 compete and 1 incomplete worm, 14 detached mature and 10 detached gravid proglottids; cross-section series of 2 detached mature proglottids; 1 scolex, 1 strobila, 2 detached proglottids, and 1 gravid proglottid disrupted to reveal eggs examined with SEM; 3 lactophenol preparations of eggs).

Worms $2.6-20.8(8.1 \pm 4.0 ; 16) \mathrm{mm}$ long, maximum width at scolex; proglottids $87-274(178 \pm 50 ; 16)$ in number, hyperapolytic. Scolex with 4 acetabula, apical modification of scolex proper and apical organ, 238-310 $(276 \pm 26 ; 14)$ long by $270-362(333 \pm 27 ; 10)$ wide. Acetabula in form of bothridia, with free posterior margins, notched posteriorly (Figs. 5B, 7A), 185-257 (217 \pm 21 ; $15 ; 27)$ long by $105-183(160 \pm 20 ; 15 ; 26)$ wide. Apical modification of scolex proper dome-shaped, with aperture at apex, housing apical organ. Apical organ spherical, 53$67(60 \pm 5 ; 15)$ long by $51-68(60 \pm 6 ; 17)$ wide, in form of conical muscular and glandular pad, non-eversible. Cephalic peduncle absent.

Scolex proper (Fig. 6D) and bothridia (Fig. 6B, C) covered with capilliform filitriches and gladiate spinitriches. Apical modification of scolex proper with capilliform filitriches and hastate spinitriches (Fig. 6E, F). Proglottids with capilliform filitriches (Fig. 6I) throughout, with gladiate spinitriches restricted to anterior spherical region

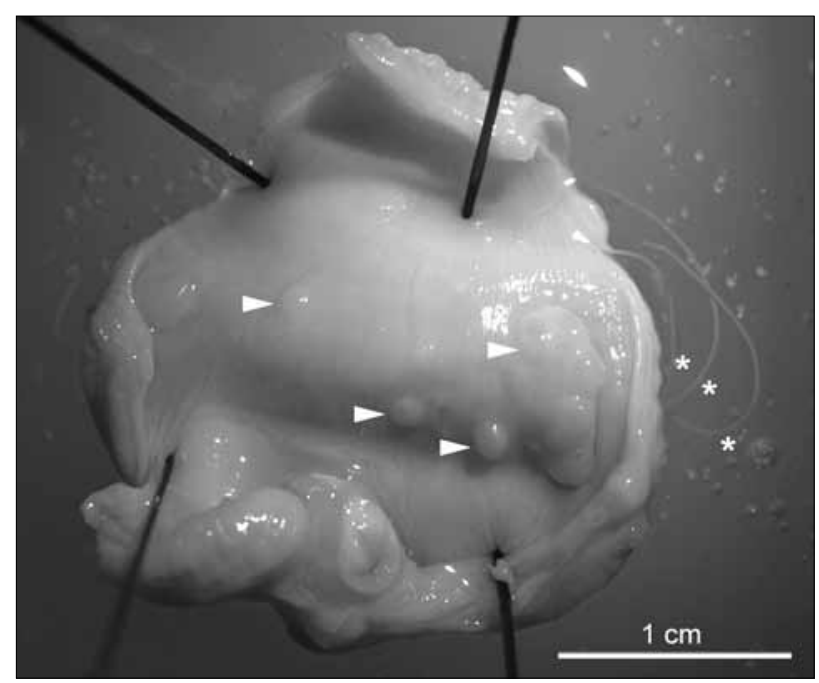

Fig. 4. Photo of the outer wall of the spiral intestine showing conspicuous papilliform expansions (arrowheads) at the points of attachment of scolices of Sesquipedalapex comicus sp. n. to the intestinal mucosa (asterisks indicate strobilae of attached specimens).

(Fig. 6J), with small scolopate spinitriches restricted to posterior margins of velum (Fig. 6K).

Proglottids craspedote, non-laciniate; immature proglottids initially wider than long, becoming longer than wide with maturity, with conspicuous anterior spherical region (Fig. 5D). Immature proglottids $72-109$ (92 $\pm 11 ; 16)$ wide; terminal immature proglottids $152-346$ (228 \pm 60 ; 16) long by $61-99(81 \pm 9 ; 16)$ wide; anterior spherical region containing large, oval cells and anterior-most testis. Detached mature proglottids 457-767 (622 $\pm 95 ; 14)$ long by $154-227(188 \pm 21 ; 14)$ wide; detached gravid proglottids $726-1,122(850 \pm 127 ; 10)$ long by $175-338$ $(260 \pm 51 ; 12)$ wide; anterior spherical region $113-194$ $(148 \pm 25 ; 12)$ long by $134-183(162 \pm 17 ; 10)$ wide in detached mature proglottids, 140-285 (180 \pm 43 ; 10) long by $144-226(199 \pm 26 ; 10)$ wide in detached gravid proglottids. Testes $4(4 \pm 0 ; 40)$ in number, arranged in single column anterior to ovary, 34-124 (64 $\pm 19 ; 24 ; 81)$ long by $60-134(91 \pm 18 ; 24 ; 81)$ wide in detached mature and gravid proglottids. Vas efferens visible in detached proglottids, forming 2 lateral ducts that extend posteriorly to level of posterior ovarian margin, uniting medially to form vas deferens (Fig. 5C, 5D). Vas deferens sinuous, extensive, extending along poral side of proglottid from oötype to enter cirrus-sac at medial margin. External and internal seminal vesicles absent. Cirrus-sac pyriform or elliptical, tilted anteriorly, anterior to, or overlapping with, second anterior-most testis, $55-113(80 \pm 16 ; 20)$ long by $30-55$ $(39 \pm 7 ; 22)$ wide in detached mature and gravid proglottids. Cirrus coiled, armed with spinitriches. Genital pores marginal to submarginal, irregularly alternating, 53-74\% $(53 \% \pm 5 ; 24)$ from posterior end, at level of second 


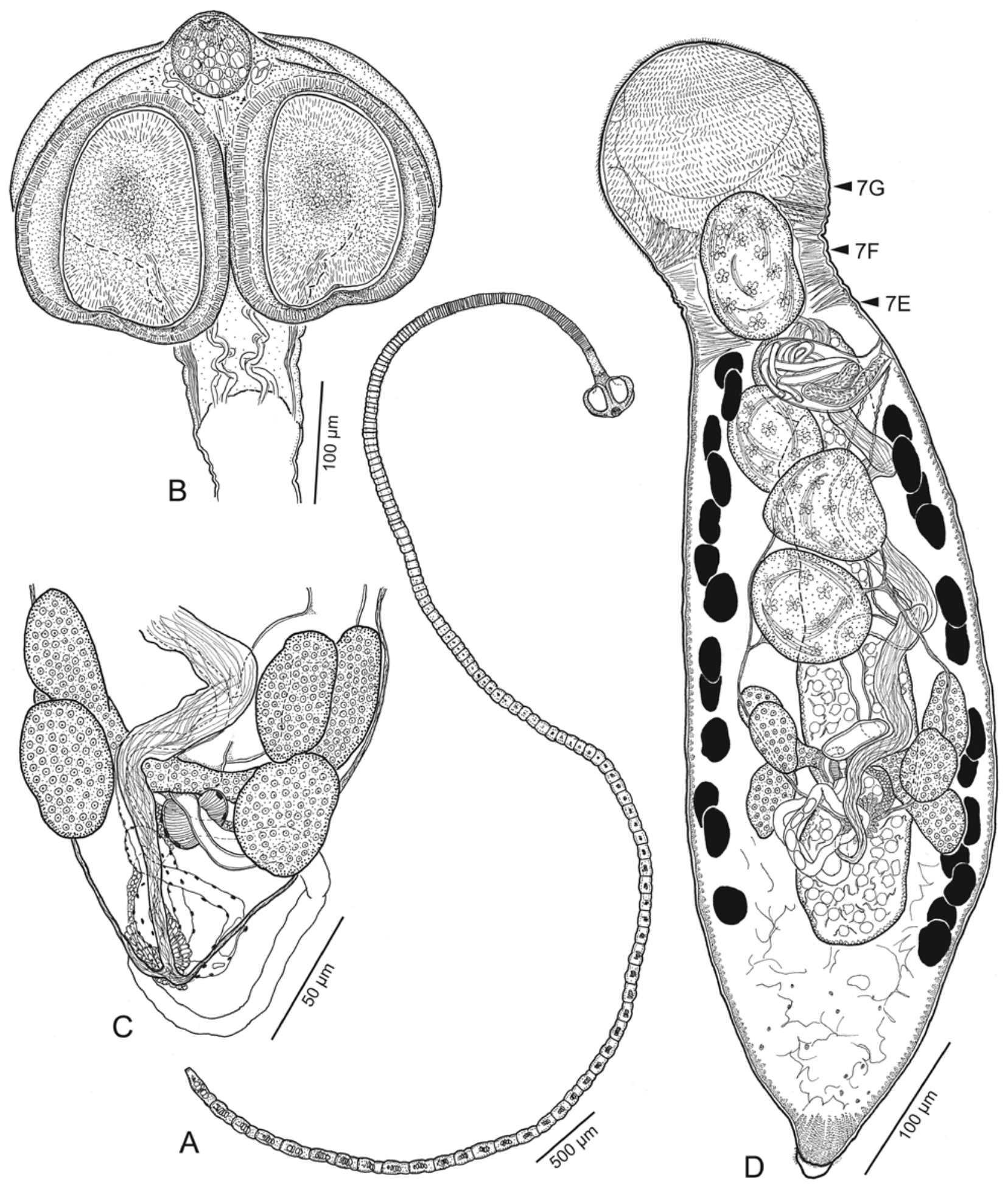

Fig. 5. Line drawings of Anteropora klosmamorphis sp. n. A - whole worm; B - scolex; C - oötype; D - detached gravid proglottid (arrowheads indicate location of sections in Fig. 7E-G). 


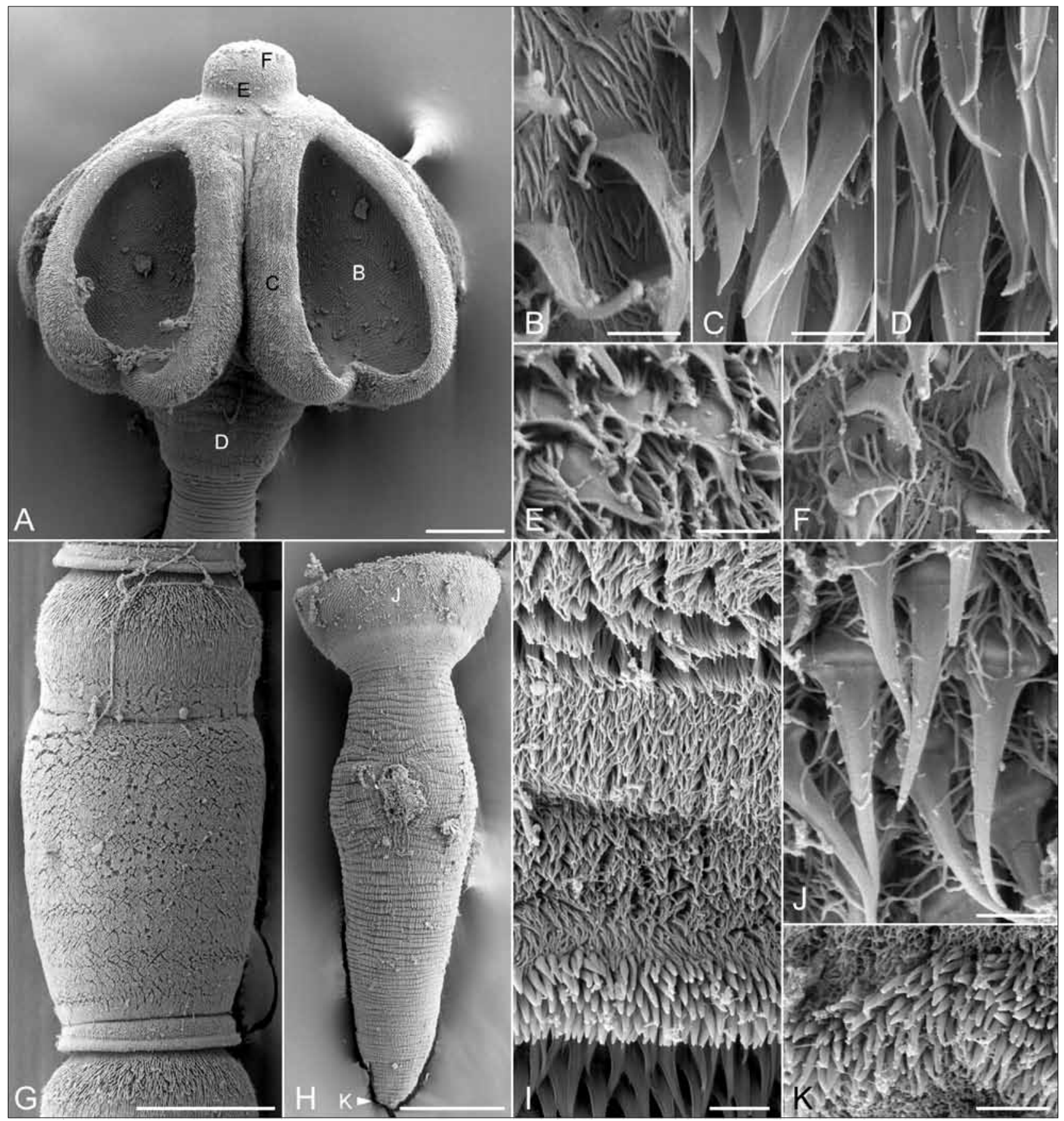

Fig. 6. Scanning electron micrographs of Anteropora klosmamorphis sp. n. A-scolex; B - distal acetabular surface with gladiate spinitriches and acicular filitriches; C, D - proximal acetabular surface with gladiate spinitriches and acicular to capilliform filitriches; $\mathbf{E}, \mathbf{F}$ - surface of apical modification of scolex proper with hastate spinitriches and acicular to capilliform filitriches; $\mathbf{G}$ - immature proglottid of strobila; $\mathbf{H}$ - detached proglottid; I - surface of posterior margin of immature proglottids with capilliform filitriches; $\mathbf{J}$ - surface of anterior region of detached proglottids with gladiate spinitriches and capilliform filitriches; $\mathbf{K}$ - surface of posterior margin of proglottid (velum) with scolopate spinitriches and capilliform filitriches. Small letters indicate location of details shown in the referenced figure. Scale bars: $\mathrm{A}, \mathrm{G}=50 \mu \mathrm{m} ; \mathrm{B}-\mathrm{F}, \mathrm{J}=1 \mu \mathrm{m} ; \mathrm{H}=100 \mu \mathrm{m} ; \mathrm{I}, \mathrm{K}=2 \mu \mathrm{m}$. 


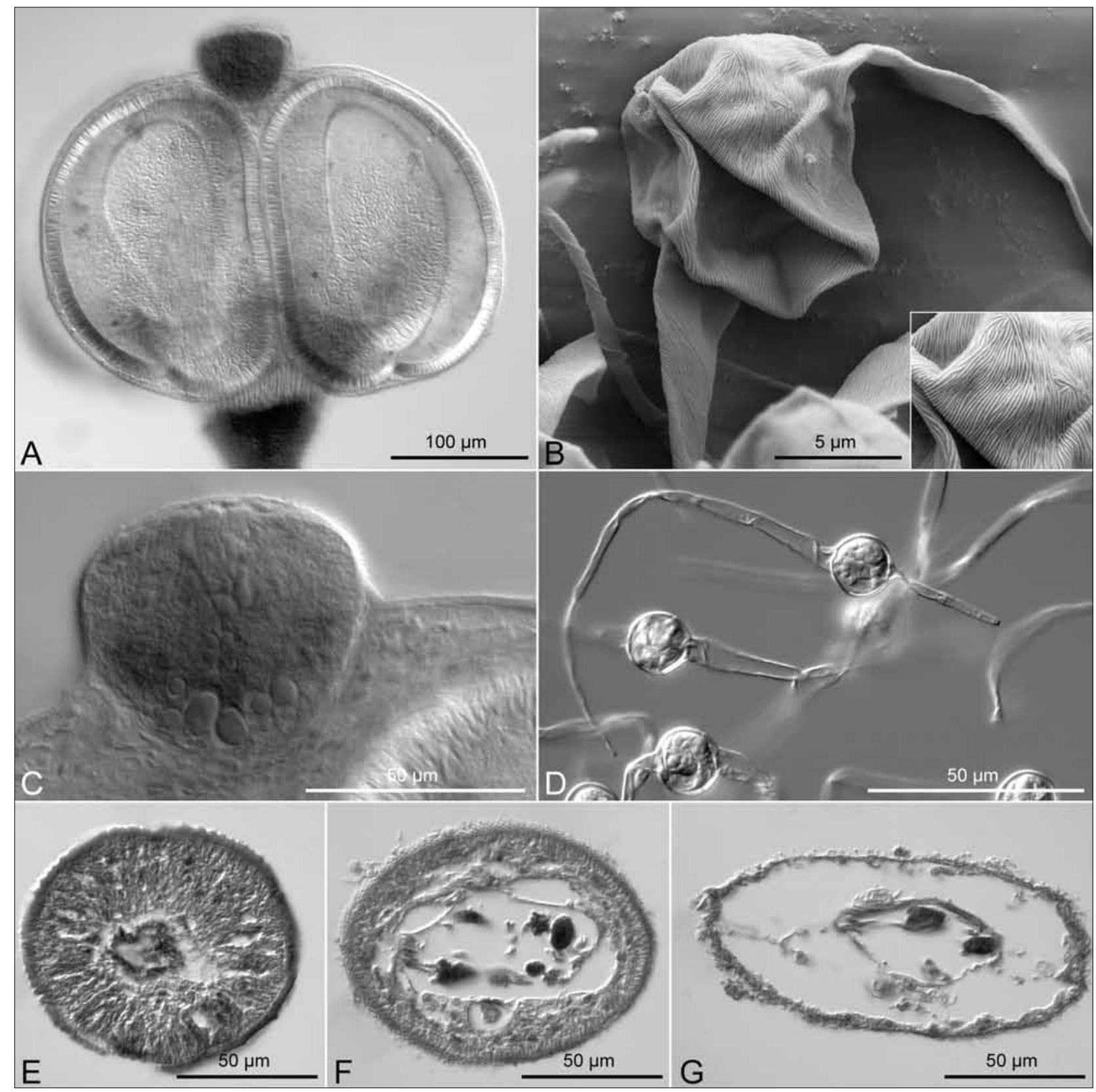

Fig. 7. Light (A, C-G) and scanning electron (B) micrographs of Anteropora klosmamorphis sp. n. A-scolex; B - egg with bipolar filaments (inset shows corrugated surface of egg and filaments); C - apical organ; D - eggs with bipolar filaments of unequal length; $\mathbf{E}$ - cross-section of detached proglottid at constriction between proglottid proper and anterior spherical region; $\mathbf{F}-$ cross-section through testis in anterior spherical region (posterior); $\mathbf{G}$ - cross-section through testis in anterior spherical region (anterior), showing vacuous nature of spherical region.

anterior-most testis. Ovary essentially H-shaped in frontal view, consisting of 3 lobes on each side, irregular in crosssection, 32-98 $(70 \pm 20 ; 14)$ long by $58-126(96 \pm 20 ; 12)$ wide in detached mature proglottids, 69-173 (114 $\pm 35 ; 9)$ long by $85-253(184 \pm 61 ; 9)$ wide in detached gravid proglottids. Vagina sinuous, initially thick-walled, extending from oötype region along poral side of proglottid to enter genital atrium posterior to, or at same level as, cirrus-sac; vaginal sphincter absent. Uterus thick-walled, extending along median line of proglottid from posterior-most vitelline follicles to proglottid constriction; when gravid, uterus occupying entire posterior region of proglottid; uterine duct joining uterus posteriorly to genital atrium; uterine pore absent. Vitellarium follicular; vitelline follicles in 2 lateral fields, $9-59(26 \pm 10 ; 23 ; 69)$ long by $5-35(17 \pm 7 ; 23 ; 69)$ wide in detached mature and gravid 
proglottids; each field consisting of 1-2 irregular columns of follicles; extending from posterior to ovary to genital pore in anti-poral field and to cirrus-sac in poral field. Excretory ducts 4 , lateral, arranged in 1 dorsal and 1 ventral pair. Eggs spherical, $12-14(13 \pm 1 ; 15)$ in diameter, with corrugated surface and bipolar filaments (Fig. 7B, D) unequal in length; shorter filament $23-37$ (30 $\pm 4 ; 15)$ long; longer filament $117-162(140 \pm 12 ; 15)$ long; eggs apparently released by eversion of uterus through dehiscence at mid-level of proglottid.

Type and only known host: Narcine maculata (Shaw), the darkspotted numbfish (Torpediniformes: Narcinidae) (Host No. BO-408).

Type and only known locality: South China Sea off southern Sarawak $\left(02^{\circ} 49^{\prime} 01.2^{\prime \prime} \mathrm{N}, 110^{\circ} 52^{\prime} 47.16^{\prime \prime} \mathrm{E}\right)$, Malaysia.

Site of infection: Spiral intestine.

Type material: Holotype (MZUM[P] 2010.27[H]), 6 paratypes ( 2 complete worms, 2 detached mature and 1 detached gravid proglottid; 1 lactophenol preparation of eggs) (MZUM[P] 2010.28[P]-33[P]); 5 paratypes (2 complete worms, 2 detached mature and 1 detached gravid proglottid) (SBC P-00031-00035); 5 paratypes (2 complete worms, 2 detached mature and 1 detached gravid proglottid) (IPCAS C-596); 16 paratypes (5 complete and 1 incomplete worm, 4 detached mature and 4 detached gravid proglottids; crosssection series of 1 detached mature proglottid; 1 lactophenol preparation of eggs) (USNPC 104127), 13 paratypes (4 complete worms, 4 detached mature and 3 detached gravid proglottids; cross-section series of 1 detached mature proglottid; 1 lactophenol preparation of eggs) (LRP 7494-7507); 4 paratypes prepared for SEM retained in senior author's personal collection.

Etymology: This species is named for the unusually elongate and slender form of its strobila (i.e., klosma, n., Gr., thread; morphe, f., Gr., form).

Remarks. Anteropora klosmamorphis conspicuously differs from A. japonica and A. leelongi in its possession of 4 , rather than 6 , testes per proglottid, in its possession of acetabula that are notched, rather than intact posteriorly, and in that its apical organ is narrower than those of both species (53-67 vs. 160 and 134-145, respectively). In addition, the vitelline fields extend much more anteriorly in A. klosmamorphis than they do in either of the other two species (i.e., to posterior margin of anterior-most testis vs. to level of posterior-most testis and to midlevel of testicular field, respectively).

With respect to $A$. indica, comparisons were hampered by the fact that this species is known only from detached proglottids, misinterpreted by Subhapradha (1955) to represent a cestodarian body, and also because the original description provides little morphometric detail. Nonetheless, no proglottids with fewer or greater than 4 testes were seen in A. klosmamorphis, whereas Subhapradha (1955) reported finding a few specimens with 3, 5 or 6 testes in $A$. indica. In addition, the spinitriches on the anterior regions of detached proglottids of $A$. klosmamorphis were slightly smaller than those seen in $A$. indica (5-6 vs. 9), as were the eggs (12-14 vs. 15). Whereas Subhapradha (1955) reported the uterus of $A$. indica to have a ventral extension posterior to the ovary in a few specimens, we found this to be the case in all of the proglottids examined here. At this time, we consider $A$. klosmamorphis to be sufficiently distinct from $A$. indica as to justify its recognition as a new species; examination of complete specimens of $A$. indica, and the scolex in particular, would be particularly illuminating. It should be noted that Tian et al. (2008) used the name "Anteropora xiamenensis sp.nov." for a specimen they included in their phylogenetic analysis. Anteropora xiamenensis should be considered a nomen nudum since the species does not appear to have been described by Tian et al. (2008); nor, as the paper implies for other taxa given new taxon designations, was it described elsewhere.

\section{DISCUSSION}

The somewhat unconventional history of Anteroporidae was reviewed by both Euzet (1994) and Jensen (2005). However, the descriptions of Anteropora japonica (as Discobothrium japonicum Yamaguti, 1934) by Yamaguti (1934) and of Anteropora leelongi by Jensen (2005), have done much to stabilize this genus, and thus also the family. The descriptions here of two additional species and a second genus, provide further insight into the morphology of the family. However, in order to accommodate these new taxa, the most recent diagnosis of the genus, provided by Jensen $(2005 ;$ p. 71$)$, requires slight modification. The distribution should be emended to read "Western Pacific Ocean (Japan, Australia, and Borneo)", and the list of hosts should be updated based on current elasmobranch classification (Froese and Pauly 2010) to read "Parasites of numbfishes (Narcinidae) and the epaulette shark, Hemiscyllium ocellatum (Hemiscylliidae)." In addition, the diagnosis of the family, as presented by Euzet (1994), should be revised to incorporate the scolex apical structure terminology suggested by Caira et al. $(1999,2001)$ and adopted by Jensen (2005) for the Lecanicephalidea in general, as well as to accommodate the new taxa described here. The revised diagnosis is as follows:

\section{Anteroporidae Euzet, 1994}

Diagnosis: Scolex with short or extremely long apical modification of scolex proper, apex expanded to accommodate muscular and/or glandular apical organ, with 4 acetabula in the form of bothridia or suckers. Strobila craspedote, hyperapolytic. Genital pores marginal or submarginal, irregularly alternating. Testes few (usually 4 or 6) aligned along median axis of proglottid. Ovary lobate, with 2-3 lobed on each side, posterior. Vagina opening 
into genital atrium posterior to, or at same level as, cirrussac. Vitellarium follicular; vitelline follicles arranged in 2 lateral bands; bands extending from posterior to ovary to near genital pore. Uterus saccate. Eggs with or without bipolar filaments; surface of eggs corrugated or with papilliform protuberances. Type genus: Anteropora Subhapradha, 1955. Additional genus: Sesquipedalapex gen. n. Parasites of numbfishes (Narcinidae) and the epaulette shark, Hemiscyllium ocellatum (Bonnaterre) (Hemiscylliidae).

This brings the total number of genera of Anteroporidae to two, and the total number of species in the family to five. The host associations of this family are intriguing. Collectively, four of the five species have been described from three species in two of the nine genera of numbfishes (Narcinidae). It also suggests that the remaining 21 species and seven genera of Narcinidae may be likely sources of additional species of Anteroporidae. The two genera and 14 species of the second family of Torpediniformes (i.e., Torpedinidae, electric rays) would also be interesting to explore. Although cestode records from some of the other members of both families of electric rays exist (e.g., Monticelli 1893, Linton 1900, Alexander 1963, Campbell and Carvajal 1987, Caira and Burge 2001), such reports do not include lecanicephalideans. However, in all but the latter case, it is not clear if this is because no lecanicephalideans were found, or if lecanicephalideans were merely not the focus of such studies.

Although the report of the remaining species in the family, Anteropora leelongi, by Jensen (2005), from the epaulette shark, Hemiscyllium ocellatum, seems incongruous given the host associations of the other species of Anteroporidae, this association has been confirmed by the third author from new material collected in Cairns, Australia in 2001. Clearly, any of the six other species of Hemiscyllium Müller et Henle, none of which have been examined for cestodes, would be particularly interesting to explore.

Sesquipedalapex comicus exhibits intriguing variations in several morphological attributes that have not been observed in any of the five species of Anteropora. For example, not only do the ducts of the excretory system of $S$. comicus exhibit lateral branching, but these ducts appear to open to the outside of the worm at numerous points, particularly along the length of the scolex of the worm. These openings are clearly visible with SEM as pores surrounded by capilliform filitriches (Fig. 2E). The implications of these modifications for the functioning of the excretory system are unclear, but would suggest fairly major differences in the operation and/or performance of this system between members of these two genera.

Also intriguing are the modes of attachment seen among members of the Anteroporidae. The proglottids are hyperapolytic and bear dense concentrations of gladiate spinitriches on an anterior, spherical expansion of free proglottids of all ages in all five species in both genera. As noted by several authors previously (e.g., Subramanian 1939, Rees and Williams 1965, McCullough and Fairweather 1983), it seems likely that the gladiate spinitriches on the anterior expanded region of the free proglottids may serve to aid in attachment of these tiny entities to the gut of their host. Hundreds of free proglottids of $S$. comicus and A. klosmamorphis were found in the contents of the spiral intestine of the specimen of Narcine maculata examined here. In fact, given the morphological similarities between these two cestode species, the determination of specific identities of these free proglottids was particularly challenging. These results lend support to McCullough and Fairweather's (1983) hypothesis that hyperapolysis may serve to allow the accumulation of reproductive proglottids in the gut, without overburdening the strobila of their respective worms with proglottids. Sesquipedalapex comicus and Anteropora klosmamorphis join Trilocularia acanthiaevulgaris Olsson, 1866 (see McCullough and Fairweather 1983), Yorkeria salputium Caira, Jensen et Rajan, 2007 (see Caira et al. 2007), and Acanthobothrium margiae Fyler, 2011 (see Fyler 2011) as the fourth and fifth species of elasmobranch-inhabiting cestodes that exhibit what was termed extreme hyperapolysis by Fyler (2011).

Sesquipedalapex comicus is further unusual among the members of its family in the method the worm itself employs to attach to the mucosal surface of the spiral intestine. As noted above, these worms appear to induce a host response in the form of a blister-like/papilliform expansion of the outer wall of the spiral intestine. The fact that their attachment to the internal mucosal surface is manifested on the external surface of the spiral intestine, suggests that these worms have a rather substantial impact on their host. Unfortunately, dissection of these mucosal papillae was required to remove intact worms for study and thus it was not possible to examine the nature of this host response using histology. However, within each papilliform expansion, multiple worms were found, intertwined around one another. Although the mode of attachment has not been studied in species of Anteropora, a conspicuous host response has never been reported at the site of attachment of any of the four species and it was certainly not seen in specimens of $A$. klosmamorphis examined here.

Not much information exists about variation in egg morphology in lecanicephalideans in general, since only individual records exist for individual species in some genera. For example, Jensen (2001) described the eggs of Paraberrapex manifestus Jensen, 2001 as being grouped in a cocoon, while Jensen (2005) described the eggs of Polypocephalus helmuti Jensen, 2005 as single with bipolar filaments in younger gravid proglottids, and contained in a fibrous matrix in older gravid proglottids. With the description of the two new species of Anteroporidae in this study, egg morphology has now been described for 
four of the five species in the family. Interestingly, egg morphology varies remarkably between genera. Three of the four species of Anteropora (i.e., A. japonica, A. leelon$g i$ and $A$. klosmamorphis) have eggs with polar filaments of unequal length (Yamaguti 1934, Jensen 2005), while the eggs of Sesquipedalapex comicus do not have polar filaments and are perfectly spherical. In addition, the egg surface of A. klosmamorphis is corrugated, while the egg surface of $S$. comicus is covered by small protuberances. Investigation of egg morphology in the Lecanicephalidea more broadly might reveal surprising diversity.
Acknowledgements. We thank Ms. Annie Lim and Mr. Albert Gambang of the Fisheries Research Institute in Kuching for arranging for JNC to participate in the cruise on the K.K. Manchong on which the host of these new cestodes was collected. This material was collected under permit No. UPE:40/200/19SJ.924 from the Economic Planning Unit in Kuala Lumpur and research agreement No. SBC-RA-0050-JNC from the Sarawak Biodiversity Center in Kuching. This work as supported with funds from National Science Foundation BS\&I grants DEB 0103640, 0542846, and 0542941 and NSF PBI grants DEB 0818696 and 0818823 .

\section{REFERENCES}

Alexander C.G. 1963: Tetraphyllidean and diphyllidean cestodes of New Zealand selachians. Trans. R. Soc. N. Z. 3: 117-142.

Caira J.N., Burge A.N. 2001: Three new species of Acanthobothrium (Cestoda: Tetraphyllidea) from the ocellate electric ray, Diplobatis ommata, in the Gulf of California, Mexico. Comp. Parasitol. 69: 52-65.

Caira J.N., Jensen K., Healy C.J. 1999: On the phylogenetic relationships among tetraphyllidean, lecanicephalidean and diphyllidean tapeworm genera. Syst. Parasitol. 42: 77-151.

Caira J.N., Jensen K., Healy C.J. 2001: Interrelationships among tetraphyllidean and lecanicephalidean cestodes. In: D.T.J. Littlewood and R.A. Bray (Eds.), Interrelationships of the Platyhelminthes. Taylor and Francis, London and New York, pp. 135-158.

Caira J.N., Jensen K., Rajan C. 2007: Seven new Yorkeria species (Cestoda: Tetraphyllidea) from Borneo and Australia and their implications for identification for Chiloscyllium (Elasmobranchii: Orectolobiformes) species. J. Parasitol. 93: 357-376.

Campbell R.A., Carvajal J.G. 1987: Phyllobothrium discopygi, n. sp. (Cestoda: Tetraphyllidea) from Chile, with a critical comparison of the affinities of $P$. auricula van Beneden, 1858 and P. foliatum Linton, 1890. Syst. Parasitol. 10: 159-164.

Chervy L. 2009: Unified terminology for cestode microtriches: a proposal from the International Workshops on Cestode Systematics in 2002-2008. Folia Parasitol. 56: 199-230.

Euzet L. 1994: Order Tetraphyllidea Carus, 1863. In: L.F. Khalil, A. Jones and R.A. Bray (Eds.), Keys to the Cestode Parasites of Vertebrates. CAB International, Wallingford, Oxon, UK, pp. 149-194.

Froese R., Pauly D. (Eds.) 2010: FishBase. World Wide Web electronic publication. www.fishbase.org, version 05/2010.
Fyler C.A. 2011: An extremely hyperapolytic Acanthobothrium species (Cestoda: Tetraphyllidea) from the Japanese wobbegong, Orectolobus japonicus (Elasmobranchii: Orectolobiformes) in Taiwan. Comp. Parasitol. 78: 4-14.

JENSEN K. 2001: Four new genera and five new species of lecanicephalideans (Cestoda: Lecanicephalidea) from elasmobranchs in the Gulf of California, Mexico. J. Parasitol. 87: 845-861.

Jensen K. 2005: Tapeworms of Elasmobranchs (Part 1). A monograph on the Lecanicephalidea (Platyhelminthes, Cestoda). Bull. Univ. Nebr. State Mus. 18: 241 pp.

Linton E. 1900: Fish parasites collected at Woods Hole in 1898. U. S. Fish. Comm. Bull. for 1899, pp. 267-304.

McCullough J.S., Fairweather I. 1983: A SEM study of the cestodes Trilocularia acanthiaevulgaris, Phyllobothrium squali and Gilquinia squali from the spiny dogfish. Z. Parasitenkd. 69: 655-665.

Monticelli F.S. 1893: Intorno ad alcuni elminti della collezione del Museo Zoologico della Reale Università di Palmero. Nat. Sicil. 12: 167-180, 208-216.

Rees G., Williams H.H. 1965: Observations on Acanthobothrium coronatum (Rud. 1819) (Cestoda: Tetraphyllidea) from Scyliorhinus stellaris (L.). (Abstract). Parasitology 55: 23.

SubHapradha C.K. 1955: Cestode parasites of fishes of Madras Coast. Indian J. Helminthol. 7: 41-132.

Subramanian M.K. 1939: Studies on cestode parasites of fishes. I. Biporophyllaeus madrassensis, gen. et sp. nov., with a note on its systematic position. Rec. Indian Mus. 41: 131-149.

Tian H.-M., Li H.-T., Zhou L., Wang Y.-H. 2008: The molecular systematic analysis of cestodes of marine fishes in Taiwan Strait. Acta Zootaxon. Sin. 33: 294-300. (In Chinese.)

Yamaguti S. 1934: Studies on the helminth fauna of Japan. Part 4. Cestodes of fishes. Jpn. J. Zool. 6: 1-112. 